\title{
"Why I Write"; Corresponding Elements in the Poetic Discourse of Jibanananda and Wordsworth
}

\author{
Firoze Basu \\ Assistant Professor, \\ Department of Humanities and Management Sciences \\ MCKV Institute of Engineering \\ Liluah, Howrah-711204 \\ West Bengal, India
}

\begin{abstract}
In his Bengali treatise on poetry named Kobitar Kotha/Why I Write there is evidence of vernacular poet Jibanananda (1899-1954). Jibanananda was familiar with the poetic cannons of European poetry. He emphasizes, in his treatise on poetry, on "experience" along with "imagination" as intrinsic to the creative process of poetry. The affinity of English Romantic poet William Wordsworth's (deliberation on nature of Poetry and the definition of a Poet in Preface to The Lyrical Ballads and Jibanananda's two articles on the same subject-Kobitar Kotha/The Story of Poetry and Keno Likhi/Why I Write is remarkable. This paper seeks to identify some areas of commonality in this sphere.
\end{abstract}

Keywords- Imagination, Poetic Diction, Tranquillity Kobitar Kotha/About Poetry, Keno Likhi/Why I Write

\subsection{Imagination as the "Unusual Light"}

The Preface to Lyrical Ballads has, with the passage of time, assumed a position of abiding importance and significance in the history of English literature. Wordsworth made a number of revisions in it over several years. The Lyrical Ballads came out first in 1798, accompanied by a short Advertisement or foreword, in which Wordsworth had set forth the main points of his argument. He said that the poems were in the nature of an experiment written to find out if themes of common life were suitable for poetry. A more elaborate 
preface was added to the 1800 edition of the Lyrical Ballads, which also contained many new poems. The Preface was enlarged and improved for the edition of poems brought out in 1802 . The most significant addition to this Preface was an account of the nature and function of a poet. The poet is declared to be superior to the man of science. The nature of poetic pleasure is also considered. To the 1802 Preface Wordsworth also added an Appendix on Poetic Diction, in which the history and nature of 'poetic diction' is considered.

Wordsworth continued to revise the Preface for each new edition of the Lyrical Ballads. According to Jibanananda Imagination is the power that enables the poet to overcome the barrier between the particular and the external and transforms the apparent world into a world of higher import and the poet conceives the essential nature of his object and sees it in its basic reality. This is reminiscent to Wordsworth's conception of imagination as a creative power. The 'unusual light of imagination' identified by Jibanananda can be directly associated with Wordsworth's technique of selection of incidents from humble and rustic life as themes and adding a tinge of imagination to make them appear in an unual light

In Preface To the Lyrical Ballads Wordsworth observes that the excellence of poetry does not lie in the "action and situation" but in the poet's intensely subjective feeling toward his experience: The "feeling [of the poet] therein developed [that is, in the poet's mind] gives importance to the action and situation [expressive theory], and not the action and situation to the feeling [mimetic theory]. He states that the poet does not simply imitate the world, but "throw[s] over "incidents and situations from common life" "a certain colouring of imagination", the imagination being that part of the human mind that creates poetry. This is echoed by Jibanananda, who in Kobitar Kotha observes "that poetry is even a re-organization of reality. It is, as if we are entering a new world - if we can visualize a new water different from all the waters of the world, a light which is similarly different then we can think of a new use (of these symbols) leaving behind the days, nights, humans and their aspirations, all the dust, skeletons and stars of creation then this use is poetry - which has with life and reality a hidden connection - a connection grey yet new. In Creation sometimes such sounds are heard, such hues are seen, or human experiences are encountered that or such profound pain is felt that we believe that such objects were reflected for a long time not disorganized 
but in organized state. And they will remain, till the last Zafran (the colour orange) sunshine. The manifestation of such experiences creates sensations in the heart. And as that mirrored landscape is slowly articulated, music is born. This essential unity between object and music achieves a unity in the poetic vision of some - and poetry is born". (My translation). Since his definition of poetry stresses on the poet, Wordsworth enumerates what qualities make a person a poet: He asks, "What is a Poet?". A poet "is a man speaking to men" but one who "is endowed with more lively sensibility" and has a greater knowledge of human Nature, and a more comprehensive soul" than other people. The poet sees the "similitude in dissimilitude and dissimilitude in similitude". a man, it is true, endowed with more lively sensibility, more enthusiasm and tenderness, who has a greater knowledge of human Nature, and a more comprehensive soul, than are supposed to be common among mankind; (About the poems chosen in Preface)- "Humble and rustic life was generally chosen, because, in that condition, the essential passions of the heart find a better soil in which they can attain their maturity, are less under restraint, and speak a plainer and more emphatic language; because in that condition of life our elementary feelings coexist in a state of greater simplicity, and, consequently, may be more accurately contemplated, and more forcibly communicated; because the manners of rural life germinate from those elementary feelings, and, from the necessary character of rural occupations, are more easily comprehended, and are more durable; and, lastly, because in that condition the passions of men are incorporated with the beautiful and permanent forms of Nature.. For our continued influxes of feeling are modified and directed by our thoughts, which are indeed the representatives of all our past feelings; and, as by contemplating the relation of these general representatives to each other, we discover what is really important to men, so, by the repetition and continuance of this act, our feelings will be connected with important subjects. "Here we can directly co-relate to two important aspects of Jibanananda's poetry his Itihaschetana- (consciousness of history) which to Wordsworth is "the representatives of all our past feelings") - from the ancient civilizations of Egypt, Babylon which abound in poems- Bonolota Sen and Piramid and the fact that he considers rural life and rural occupations to be superior.

We who have walked the through the fields of hay...

Seen women scattering flowers in the soft rivers... 
before Death what more do we want to understand?"

MrityurAage/Before Death

Have I not picked up the plough/Pulled water in the buckets

.I have felt the taste of such.. Bodh/ Sensation

Regarding his idea of Itihaschetana or consciousness of history Jibanananda observes in Kobitar Kotha- Not all are poets... only those whose sensibilities are honed by centuries of historical sense before them and new innovations taking place in the modern sphere. Wordsworth insists that the poet differs from other men not "in kind," "but only in degree"). Two degrees of difference are listed: The poet is better able "to think and feel without immediate external excitement" and "he has a greater power in expressing [his] thoughts and feelings" than non-poets "

According to Jibanananda- 'There is an element within pure poetry that is hidden, not openly demonstrated and only manifests itself gradually 'In Wordsworth's poems, the humblest of people are exalted to the highest dignity and worth. That is, he felt, that the poet's imagination could make commonplace happenings take on a quality of magic: He sought "to throw over them a certain colouring of imagination, whereby ordinary things should be presented to the mind in an unusual aspect" (242). This has been reiterated time and again by Jibanananda not only in the articles mentioned but also in a letter written to Tagore where he emphasizes the uniqueness of the imagination to see colours beyond what they -the colour of the sky, grass can be different from what they are in actuality. Wordsworth says, "My purpose [in his poems] was to imitate, and, as far as possible, to adopt the very language of men" (244). He takes pride that there "will also be found in [his poems] little of what is usually called poetic diction" (244). He desires "to bring my language near to the language of men" (244). Thus, he says, his poems use "the language of [common, ruralbased] men[since] such a language arising out of repeated experience and regular feelings, is a more permanent, and a far more philosophical language, than that [poetic diction] which is frequently substituted for it by Poets, who think that they are conferring honour upon themselves and their art, in proportion as they separate themselves from the sympathies of men" (242-43). Jibanananda does not directly address poetic diction but avoids the classical 
Sanskrit in the poems and does use provincial words like phede (to tear) semij (a type of clothing), ghai (a species of deer).

\section{The 'True' Purpose of Poetry}

According to Wordsworth the purpose of poetry is "Immediate pleasure and enduring truth", "The poet writes under one restriction only, the necessity of giving immediate pleasure" to the reader, However, the poet never forgets that the central purpose of true poetry is the recording of truth: "The object [of poetry] is truth, not individual and local, but general, and operative; not standing jupon external testimony, but carried alive into the heart by passion" And Jibanananda maintains- "poets have to have a happy mix between imagination and experience.I do not agree with those who maintain poetry has to conform to the strict rules or conventions of poetic ideals laid down.. There is a clear link between poetry and life (reality). But it is not openly demonstrative. And looking at stark reality the imaginative powers - Kalpana Protibha (imaginative power) of the poet is not satisfied. But through the articulation of his poetic vision -Kobita Manisha (poetic vision) through poetry he is satisfied and so are his readers Wordsworth affirms here is that the poet's emotions presented in the poem arouse in the reader emotions similar to the poet's. So communication between the poet and the reader takes place in the realm of the emotions not that of ideas, not a higher plane of Platonic ideals, not even in mirroring or imitating the world around us. But in the reality of emotions both poets stress on the immortal quality which is a prerequisite of poetry and scoff at the popular and contemporary works which have little value beyond the immediate gratification of the reader. According to Wordsworth 'The invaluable works of our elder writers, I had almost said the works of Shakespeare and Milton, are driven into neglect by frantic novels, sickly and stupid German Tragedies, and deluges of idle and extravagant stories in verse-When I think upon this degrading thirst after outrageous stimulation, I am almost ashamed to have spoken of the feeble endeavour made in these volumes to counteract it.' According to Jibanananda in Kobitar Kotha- "When one perceives inferior poets and musicians being appreciated over really talented ones it is clear that the appreciation of the subtle against the crass is only the indoctrinated few, not for all What will the true poet do if the crass and the mundane prevail? He has to remain true to his talent. Maybe someday his poems will be required as seeds to weave a golden, immortal crop." 
Jibanananda was preoccupied with the difference between the self and world around a difference that never could be bridged. In this context Jibanananda was more influenced by the 19th century Romantics than the Modern poets. In his response to beauty and feeling of fatigue Jibanananda is a romantic and in his use of imagery response to sensations and desire to escape, he is closest to Keats. But classical unity, not a loose structure is the main characteristic of Keats's odes unlike Jibanananda. In this context, Wordsworth, while articulating personal emotions was never an individualist his poems reflect "the explicit social and moral preoccupation of his self communings in solitude." In KobitarKotha, Jibanananda makes two observations regarding the nature of poetry which can be deliberated upon. He observes that true poetry cannot involve a pre-meditated reflection on the problems of society. Also poetry and life are two expressions of same thing. It can be argued that true poetry can involve social problems

Jibanananda's poetry has in its unobtrusive way almost ushered in a new poetic diction. M.H Abrams also perceives Wordsworth as a radical poet who deviates from the 'norm'. He sees Wordsworth's ideology as a violation of the tradition of the literary world in that he chooses to use the language of common man, in his poetry while the classical poets before him often picked high diction Poetic diction is usually defined as "words and phrases which have established themselves as appropriate to poetry because they are not used in speech.'(Tarvin4)What kind of language is appropriate for poetry? Aristotle, Longinus,Horace, Dante, Sidney, Dryden, Pope, and Johnson had all advocated to a certain degree that a serious poet should use a lofty style. They basically contend that the language of literature, whether poetry or drama, should be different from the language used in the real world. Wordsworth opposes this view, and in so doing makes an objective analysis of the language of poetry.. First, he says that some poets believe they must "use a peculiar language". On the contrary, he asserts, a poet "must descend from this supposed height" and "express himself as other men express themselves".Thus Wordsworth objects to the "poetic diction" so prevalent in the poetry of his time. Jibananada would oscillate he would favour the use of commonplace language but at the same time use-new and exotic words like ghaiharini-Campe. William also believes that William Wordsworth laid the foundation of the later poets to build on. He asserts; As a poet, Wordsworth identified early on with contemporary 
trends and began to write on ways specifically designed to challenge orthodox literary conventions. Producing in consequence poetry guaranteed to make a reading public for his handiwork to be retained and established. William (1996) also believes that William Wordsworth laid the foundation of the later poets to build on. He asserts;As a poet, Wordsworth identified early on with contemporary trends and began to write on ways specifically designed to challenge orthodox literary conventions. Producing in consequence poetry guaranteed to make a reading public for hishandwork to be retained and established.3 J. R. Watson asserts that when he is considered alongside the other Romantic poets, what is so extraordinary about Wordsworth is not his evocation of Nature, but his insight into the Nature of man with individually and in society.Watson maintains that Wordsworth is a sociological poet, who is concerned with the affairs of man, especially the downtrodden and the spoken of, in the society.All these observations bear a degree of affinity for Jibananada as well. He would use a mix of Sadhu-Chalit (the pure and common)form of Bengali. Jibananada would indulge in prose poetry withal its languid metrical nuances resonating the former's observation about there being no difference between the language of poetry and prose.

\section{Conclusion}

The role of Imagination in the scheme of all poetic aspirations is the central theme that unites two apparently dissimilar poets separated by geographical, linguistic boundaries and nearly two hundred years. That Jibanananda was a poet of solitude has been commented upon at length by Buddhadeb Bose, Clinton Seely and other poets and critics Jibanananda would actually live the life of the poet as visualized by Wordsworth. Several of Jibanannada's poems present the image of the poet as a solitary/Nirjan figure observing his surroundings in tranquillity with a detached air.

\section{Works Cited}

Literary Criticism: A Short History, William K. Wimsatt Jr and Cleanth Brooks. Oxford \& IBH Publishing Co. Indian Edition, p. 387

Rolfe, Williams, J. William. Wordsworth, Selected Poems of William Wordsworth. New York: American Book, 1999. 
Wordsworth, William. The Poetical Works of Wordsworth. Oxford University Press. London, 1960.

The Harvard Classics. 1909-14. Preface to Lyrical Ballads William Wordsworth (1800)

Abrams M.H, The Mirror and the Lamp: Romantic Theory and the Critical Tradition (1953)

Bandopadhaya, Deviprasad: "Kabya Songroho - Jibanananda Jibanananda. Collection of Poetry of Jibanananda, 1993, Bharbi,13/1 Bankim Chatterjee Street, Kolkata-73.

Chaudhuri,Sukanta (ed): “A Certain Sense - Poems by Jibanananda Das”, Translated by Various Hands, 1998, Sahitya Akademi, Kolkatta. 2006.

Bandopdhaya, Deviprasad. Jibanananda. Uttorparba (1954 - 1965), Pustak Bipani, Calcutta, 2000.

Bandopdhaya, Deviprasad. Kabya Songroho - Jibanananda. Trans. Collection of Poetry of Jibanananda, Dhaka, Bangladesh: Gatidhara, 1999.

Das Sisir Kumar. 'Introduction to "A Certain Sense"، Poems by Jibanananda Jibanananda. Translated by various hands and edited by Sukanta Chaudhuri. New Delhi: Sahitya Akedemi, 2000.

Basu, Ambuj: "Ekti Nakshatra Ashe”, 1999, Bharbi, Kolkata-73

Chowdhury, F.L.(ed): Oprokashito 54 (tr.Unpublished-rift7 one poems of Jibanananda Jibanananda),1999,Mawla Brothers, Dhaka.

Mukhopadhay, Tarun. Kobi Jibanananda Onuvabe, Onudhanye, 2000, Barna Pustakalaya,

Seely, Clinton B: A Poet Apart" (A comprehensive literacy biography of JibananandaJibanananda,1990, Associated University Press Ltd, USA.

Seely,Ciinton B. "Scent of Sun"(An anthology of ·poems of Jibanananda Jibanananda in English translation). 2008

Shahriar, Abu Hasan. Jibanananda Jibanananda-er Gronthito-Ogronthito Kabita Samagra, Agaami Prokshoni, Dhaka, 2004.

Kobi Jibanananda Jibanananda-Sanjay Bhattacharysa, "Doe In Heat:A Critical Biography of the Bengali Poet Jibanananda Jibanananda (1899-1954) With Relevant Literary History From The Mid-1920'S to the Mid-1950'S: Seely, Clinton BoothThe University of Chicago

Bandhyopadhaya, Deviprasad: Kobita Sangroho 
http://shodhganga.inflibnet.ac.in/bitstream/10603/96296/7/07_chapter\%201.pdf

Bandhyopadhaya: Deviprasad: Jibanananda Jibanananda Uttarparbo

Bivav Jibanananda Special Centenary Issue published in January 1999.

Sinha Sujata Bangla Kobita Jibanananda Aruna Prakashan - First Edition 2013

Chakraborty Sumita Jibanananda: Samaj o Samakal (A Book Dealing with Different Aspects of Jibanananda's Work) -, Sahityalok Publishers, 1987

Sankha Ghosh (Ed .), EiSamay O Jibanananda Collection of Literary Essay (New Delhi: Sahitya Akademi, 2001).

Jibanananda, Post-Rabindrian Bengali Poet Posted date on: April 13, 2011 in Alternative Modernities- JIBANANANDA, POST-RABINDRIAN BENGALI POET Debashish Banerji

Chowdhury, Faizul Latif and Golnm Mustaf a (Ed.),2008, Beyond Land and Time, Somoy Prokashon, Dhaka.

Das, Jibanananda, Kabitar Kotha, Kolkata: Signet Press,1991 